\title{
METODE PEMBIASAAN SEBAGAI UPAYA DALAM PENANAMAN KEDISIPLINAN ANAK TERHADAP PELAKSANAAN IBADAH (TELA'AH HADITS NABI TENTANG PERINTAH MENGAJARKAN ANAK DALAM MENJALANKAN SHOLAT)
}

\author{
Imas Jihan Syah a, 1 \\ ${ }^{a}$ Universitas Islam Lamongan Indonesia \\ 1 imasjihans@gmail.com
}

\begin{tabular}{l}
\hline Informasi artikel \\
\hline Received : \\
Agust 15, 2018. \\
Revised : \\
Agust 27, 2018. \\
Publish : \\
September 09, 2018. \\
Kata kunci: \\
metode pembiasaan; \\
disiplin dalam \\
beribadah
\end{tabular}

Keywords: method of habituation; discipline in worship

\begin{abstract}
ABSTRAK
Berbagai ragam metode yang ditempuh oleh orang tua atau guru sebagai pendidik sebagai upaya mengimplementasikan rencana yang telah tersusun untuk mencapai tujuan pembelajaran terhadap anak didik baik dalam kegiatan nyata ataupun praktis. Termasuk diantaranya adalah metode pembiasaan. Pada dasarnya setiap metode memiliki kelebihan dan kekurangan. Untuk itu pendidik harus mampu memilih metode dengan berbagai pertimbangan. Metode pembiasaan merupakan sebuah metode yang berlangsung dengan cara membiasakan anak didik untuk berfikir, bersikap dan berkata serta melakukan segala aktifitas yang telah ditentukan untuk menciptakan kebiasaan positif dalam kehidupan anak didik. Untuk itu, metode ini membutuhkan waktu relatif lama. Shalat merupakan pilar dari agama. Hal tersebut memerlukan pembiasaan dalam mengimplementasikannya sejak usia tamyiz, sebagaimana yang disabdakan Nabi. Pembiasaan tersebut juga berfungsi dalam menanamkan kedisiplinan terhadap anak. Namun perlu diketahui bahwa hendaknya dalam menanamkan kebiasaan tersebut pendidik harus memperhatikan: prinsip memelihara fitrah anak, diupayakan untuk mengembangkan potensi anak, bersifat mengarahkan serta dilakukan secara bertahap.

ABSTRACT
Various methods used by parents or teachers as educators as an effort to
implement a plan that has been prepared to achieve learning objectives
for students in both real and practical activities. These include
habituation methods. Basically every method has advantages and
disadvantages. For that educator must be able to choose the method with
various considerations. Method of habituation is a method that takes
place by familiarizing the students to think, behave and say and do all the
activities that have been determined to create positive habits in the life of
the students. For that, this method takes a relatively long time. Prayer is
a pillar of religion. It requires habituation in implementing it since the
age of tamyiz, as the Prophet said. Habituation also functions in instilling
discipline of children. It should be noted, however, that in instilling these
habits the educator should pay attention: the principle of preserving the
fitrah of the child, strived to develop the potential of the child, is directed
and done gradually.
\end{abstract}

This work is licensed under a Creative Commons Attribution-ShareAlike 4.0 International License. Allows readers to read, download, copy, distribute, print, search, or link to the full texts of its articles and allow readers to use them for any other lawful purpose.

\section{PENDAHULUAN}


Pembiasaan berasal dari kata dasar biasa yang mendapatkan imbuhan Pe- dan akhiran -an. Biasa merupakan hal yang lazim atau acap kali dilakukan.Teori pembiasaan merupakan serangkaian proses pendidikan yang berlangsung dengan cara membiasakan anak didik untuk bersikap, berbicara, bertindak, berfikir dan melakukan aktifitas yang telah ditentukan sesuai dengan kebiasaan yang baik.

Menurut ahli pendidikan Edward Lee Thoorndike dan Ivan Pavlov, pembiasaan sebagaimana halnya keteladanan adalah hal yang sangat dibutuhkan dalam pendidikan karena secara psikologis alasan yang mendasari pentingnya pembiasaan adalah bahwa pengetahuan, pendidikan dan tingkah laku yang dilakukan oleh manusia pada umumnya diperoleh menurut kebiasaannya. Pembiasaan dalam hal positif yang ditanamkan terhadap anak secara kontinyu atau menerus menerus akan mampu menumbuhkan watak dan karakter yang baik.

Sesuatu yang yang telah menjadi kebiasaan setiap orang yang telah lama tertanam akan sulit dihilangkan. Oleh karena itu, pembiasaan memerlukan proses dan waktu yang sangat lama hingga mampu membentu karakter seseorang menjadi manusia yang disiplin dan bermartabat baik dalam berfikir, bersikap, berbuat dan berucap.

Penanaman kebiasaan yang baik, sebagaimana sabda Rasulullah SAW di atas, sangat penting dilakukan sejak awal kehidupan anak. Agama Islam sangat mementingkan pendidikan kebiasaan, dengan pembiasaan itulah diharapkan peserta didik mengamalkan ajaran agamanya secara kontinyu dan berkelanjutan.

Pembiasaan ini akan memberikan kesempatan kepada peserta didik terbiasa didalam mengamalkan ajaran agamanya, baik secara individual maupun secara kolektif atau berjamaah dalam kehidupan sehari-hari. Semisal metode pembiasaan 
shalat, yang harus ditanamkan oleh setiap orang tua atau guru sebagai pendidik terhadap anak kecil mulai sedini mungkin yakni ketika memasuki usia 7 tahun. Rasulullah SAW. memerintahkan kepada para orang tua dan pendidik agar mereka menyuruh anak-anak mengerjakan shalat, ketika berumur tujuh tahun, sebagimana sabdanya:

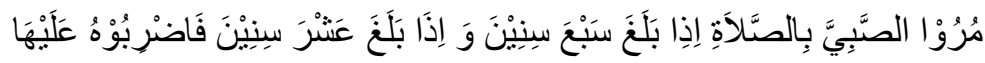

"Suruhlah olehmu anak-anak itu shalat apabila ia sudah berumur tujuh tahun, dan apabila ia sudah berumur sepuluh tahun, maka hendaklah kamu pukul jika ia meninggalkan shalat”.

Hadits ini memberikan penjelasan kepada kita tentang pengajaran pembiasaan terhadap anak dalam masalah shalat sejak berumur tujuh tahun dan diperbolehkan untuk memukulnya apabila dia meninggalkan ketika berusia sepuluh tahun. Selain itu, hadits tersebut juga menggambarkan metode pembelajaran oleh Nabi dalam mengaplikasikan metode perintah, metode pembiasaan serta metode hukuman dan ganjaran.

Namun, dalam pembahasan kali ini, penulis hanya memaparkan metode pembelajaran pembiasaan sebagai upaya pendidik dalam menanamkan kedisiplinan terhadap anak didik terutama didalam menjalankan ibadah shalat 5 waktu.

\section{Pengertian Metode Pembelajaran}

Para ahli pendidikan memberikan definisi yang berbeda-beda dalam memahami metode pembelajaran. Secara umum metode pembelajaran merupakan cara 
yang digunakan untuk mengimplementasikan rencana yang telah tersusun untuk mencapai tujuan pembelajaran baik dalam bentuk kegiatan nyata ataupun praktis. Hal ini merupakan salah satu langkah yang ditempuh oleh guru atau pendidik dalam proses belajar mengajar didalam mencapai tujuan pembelajaran untuk memperoleh hasil yang maksimal.

Menurut Abdurrahman Ginting metode pembelajaran dapat diartikan sebagai cara atau pola yang khas dalam memanfaatkan berbagai prinsip dasar pendidikan serta berbagai teknik dan sumberdaya terkait lainnya agar terjadi proses pembelajaran pada diri pembelajar. Metode pembelajaran merupakan suatu pengetahuan tentang cara mengajar yang dipergunakan oleh guru atau instruktur (Ginting, 1997:52). Adapun menurut M. Hasby Ashydiqih berpendapat bahwa, metode pembelajaran adalah seperangkat cara yang dilakukan untuk mencapai tujuan tertentu dalam proses pembelajaran. Sedangkan dalam paparan Geriach Ely dalam bukunya Strategi Dalam Proses Belajar, ia mengatakan metode pembelajaran adalah cara-cara atau upaya yang dipilih untuk menyampaikan pelajaran dalam lingkungan pengajaran tertentu, yang meliputi sifat, lingkup dan urutan kegiatan yang dapat memberikan pengalaman belajar kepada siswa. Metode pembelajaran ialah cara atau upaya yang dipergunakan guru dalam mengadakan hubungan dengan siswa pada saat berlangsungnya pengajaran (Sudjana, 2005:76).

Berdasarkan dari beberapa definisi menurut pakar beberapa pakar pendidikan diatas,bisa kita tarik kesimpulan bawha bahwa yang dimaksud metode pembelajaran adalah upaya atau cara yang ditempuh oleh guru sebagap pendidik untuk menyampaikan materi pembelajaran secara maksimal sehingga tujuan pembelajaran dapat dicapai sesuai dengan yang diharapkan. Hal ini mendorong seorang guru untuk 
mencari metode yang tepat dan efektif dalam penyampaian materi pembelajarannya agar dapat diserap dengan baik oleh siswa.

Mengajar secara efektif sangat bergantung pada pemilihan dan penggunaan metode pembelajaran. Dengan menggunakan metode pembelajaran, proses belajar mengajar nampak menarik serta menyenangkan dan tidak membuat para siswa tersebut suntuk, dan juga para siswa tersebut dapat memahami ilmu dari tenaga pendidik tersebut dengan mudah. Untuk itulah didalam memilih sebuah metode pembelajaran haruslah seorang pendidik harus memperhatikan karakteristik peserta didik. Pendidik dapat menggunakan metode yang berbeda untuk tiap kelasnya disesuaikan dengan kemampuan dan karakteristik peserta didik (siswa/murid) beserta tema yang diajarkan.

\section{Macam-macam Metode Pembelajaran}

Berikut ini merupakan macam-macan metode pembelajaran yang biasanya dipakai oleh guru didalam menyampaikan pengajarannya terhadap anak didik agar mencapai tujuan pembeljaran yang diinginkan.

1. Metode Konvensional/ metode ceramah.

Metode pengajaran dengan cara berceramah atau menyampaikan informasi secara lisan kepada siswa. Metode ini merupakan metode yang paling praktis dan ekonomis, tidak membutuhkan banyak alat bantu. Metode ini mampu digunakan untuk mengatasi kelangkaan literatur atau sumber rujukan informasi karena daya beli siswa yang diluar jangkauan. Namun metode ini juga memiliki beberapa kelemahan dan kelebihan.

2. Metode Diskusi. 
Metode diskusi merupakan metode pengajaran yang erat hubungannya dengan belajar pemecahan masalah. Metode ini juga biasa dilakukan secara berkelompok atau diskusi kelompok.

3. Metode Demostrasi.

Metode demonstrasi digunakan pada pengajaran dengan proses yaitu menggunakan benda atau bahan ajar pada saat pengajaran. Bahan ajar akan memberikan pandangan secara nyata terhadap apa yang akan dipelajari, bisa juga melalui bentuk praktikum. Metode demonstrasi ini memiliki manfaat antara lain siswa jadi lebih tertarik dengan apa yang diajarkan, siswa lebih fokus dan terarah pada materi, pengalaman terhadap pengajaran lebih diingat dengan baik oleh siswa.

\section{Metode Ceramah Plus.}

Metode ceramah plus yaitu sistem pengajaran dengan menggunakan ceramah lisan dan disertai metode lainnya. Metode mengajar ini menggunakan lebih dari satu metode. Misalnya: 1) Metode ceramah plus tanya jawab: Metode ini secara ideal disertai dengan penyampaian materi dari guru, pemberian peluang pada siswa untuk bertanya apa yang tidak dimengerti, dan pemberian tugas di akhir pengajaran; 2) Metode ceramah plus diskusi dan tugas: Metode ini dilakukan dengan memberikan materi secara lisan kemudian disertai dengan diskusi dan pemberian tugas di akhir sesi; 3) Metode ceramah plus demonstrasikan dan latihan: Metode ini merupakan gabungan dari penyampaian materi dengan memperagakan atau latihan atau percobaan.

5. Metode Resitasi 
Metode resitasi merupakan metode mengajar dengan siswa diharuskan membuat resume tentang materi yang sudah disampaiakan guru, dengan menuliskannya pada kertas dan menggunakan bahasa sendiri.

\section{Metode Percobaan}

Metode percobaan merupakan metode pengajaran dengan menggunakan action berupa praktikum atau percobaan lab. Masing masing siswa dengan ini mampu melihat proses dengan nyata dan belajar secara langsung.

\section{Metode Karya Wisata}

Metode karya wisata adalah suatu metode mengajar dengan memanfaatkan lingkungan, lokasi, atau tempat- tempat yang memiliki sumber pengetahuan bagi siswa. Metode mengajar ini dilakukan dengan pendampingan oleh guru ataupun orang tua jika usianya masih terlalu muda. Pendampingan dilakukan untuk menunjukkan sumber pengetahuan yang perlu dipahami oleh siswa. Metode karya wisata ini bisa dilakukan di tempat tempat sejarah, di alam, atau lainnya.

8. Metode Latihan Keterampilan

Metode latihan keterampilan ini merupakan metode mengajar dengan melatih keterampilan siswa atau soft skill dengan cara membuat, merancang, atau memanfaatkan sesuatu. Metode ini membutuhkan kreativitas siswa yang tinggi dengan memanfaatkan suatu bahan menjadi barang yang lebih berguna dan bermanfaat.

\section{Metode Pemecahan Masalah (Problem Based Learning)}

Metode PBL ini dilakukan dalam kelas kecil, siswa diberikan kasus untuk menstimulasi diskusi kelompok. Kemudian siswa mengutarakan hasil pencarian materi terkait kasus dan didiskusikan dalam kelompok.

\section{Metode Perancangan}


Metode perancangan merupakan metode mengajar dengan merangsang siswa untuk mampu menciptakan atau membuat suatu proyek ayang akan dipraktekkan atau akan diteliti.

\section{Metode Discovery}

Metode discovery merupakan metode pengajaran modern yang dilakukan dengan cara mengembangkan cara belajar siswa menjadi lebih aktif, mandiri, dan pemahaman yang lebih baik. Siswa mencari jawaban atas pertanyaannya sendiri, sehingga dapat diingat lebih baik. Strategi ini dinamakan strategi penemuan. Siswa menjadi lebih aktif mencari, memahami, dan menemukan jawaban atau materi terkait. Siswa juga mampu menganalisa pengetahuan yang diperolehnya kemudian ditransfer kepada masyarakat.

\section{Metode Inquiry}

Metode inquiry merupakan metode yang mampu membangun siswa untuk menyadari apa yang dia dapatkan selama belajar. Guru tetap memiliki peranan penting dalam metode ini yaitu dengan membuat design pengalaman belajar. Inquiry memiliki arti memahami apa yang telah dilalui. Metode ini melibatkan intelektual dan menuntut siswa memahami apa yang mereka pelajari sebagai sesuatu yang berharga. Srategi pelaksanaan metode inquiry ini yaitu: guru memberikan penjelasan materi yang diajarkan, kemudian memberikan tugas pada siswa untuk menjawab pertanyaan yang diajukan guru sebagai evaluasi pemahaman siswa. Guru membantu memberikan jawaban yang mungkin sulit dan membingungkan bagi siswa. Resitasi dilakukan pada akhir untuk mengevaluasi pemahaman siswa tentang apa yang sudah dipelajari. Kemudian siswa merangkum apa saja yang sudah dipelajari sebagai kesimpulan yang dapat dipertanggunjawabkan. 


\section{Mind Mapping}

Mind mapping adalah metode belajar dengan menerapkan cara berfikir runtun terhadap suatu permasalahan bagaimana bisa terjadi sampai pada penyelesaiannya. Pengajaran melalui mind mapping disajikan dalam bentuk skema yang memiliki hubungan sebab akibat dan saling berpengaruh. Metode belajar dengan mind mapping ini mampu meningkatkan analisis dan berfikir kritis siswa sehingga memahami sesuatu secara keseluruhan dari awal sampai akhir.

\section{Role Playing/ Berbagi peran}

Metode pembelajaran dengan role playing yaitu dengan metode drama atau peran. Metode ini dengan melibatkan siswa dalam berakting sebagai suatu karakter dalam suatu situasi tertentu dan menunjukkan respon yang seharusnya dilakukan. Pembelajaran melalui role playing ini melatih interaksi dan mengekspresikan diri secara nyata sebagai contoh atas kejadian yang sebenarnya. Hal ini juga bisa digunakan untuk latihan komunikasi yang baik, atau interaksi dengan orang lain atau klien.

\section{Cooperative Script}

Skrip kooperatif merupakan metode belajar dengan memasangkan siswa dan secara lisan menuntut siswa untuk mengutarakan intisari dari bagian materi yang disampaikan. Pertama, guru membagi siswa untuk berpasangan, guru membagikan materi pada siswa dan membuat ringkasan, guru menentukan siapa yang akan menjadi pembicara dan pendengar. Pembicara membacarakan ringkasannya sebaik mungkin dengan mengutarakan ide ide pokok materi, kemudian bertukar peran antara pembicara dan pendengar. Guru pada akhir sesi memberikan kesimpulan.

16. Debat 
Debat merupakan metode pembelajaran dengan mengadu argumentadi antara dua pihak atau lebih baik perorangan maupun kelompok. Argumentasi yang dilakukan membahas tentang penyelesaian suatu permasalahan dan memberi keputusan terhadap masalah. Debat pada umumnya dilakukan secara formal dengan bahasa bahasa formal dan cara cara tertentu yang sopan.

\section{Metode Mengajar Beregu (Team Teaching Method)}

Metode mengajar ini dilakukan oleh lebih dari satu pengajar, materi diberikan dengan jadwal yang berbeda oleh beberapa pengajar. Soal ujian dibuat oleh beberapa pengajar dan disatukan. Pengajar membuat soal dengan menggunakan poin poin capaian yang sudah dibuat sehingga jelas.

\section{Metode Mengajar Sesama Teman (Peer Teaching Method)}

Metode mengajar ini dilakukan dengan cara berdiskusi, atau juga dengan presentasihasil diskusi. Kelompok menyampaikan materi hasil diskusi dan memberi kesempatan pada teman- temannya untuk bertanya. Kelompok menjawab setiap pertanyaan.

\section{Metode Bagian (Teileren method)}

Metode pengajaran ini dilakukan denganmemberikan materi sebagian sebagian, misalnya belajar ayat. Pengajaran dimulai dari ayat per ayat yang kemudian disambung lagi dengan ayat lain.

\section{Metode Global}

Metode global ini mengajarkan pada siswa keseluruhan materi, kemudian siswa membuat resume tentang materi tersebut yang mereka serap dan diambil intisarinya. 
Metode metode pembelajaran diatas bertujuan untuk meingkatkan pemahaman siswa dalam memperoleh indormasi atau pengetahuan dengan efisien dan efektif. Metode pembelajaran masing masing memiliki kelebihan dan kekurangannya, sehingga tidak semua metode pembelajaran bisa diterapkan pada semua kelasa atau semua mata pelajaran. Guru perlu mencocokkan metode pembelajaran mana yang sesuai untuk kelasnya dan seusuai dengan materi yang akan dilakukan agar siswa merasa tertarik dalam belajar dan memiliki pemahaman yang baik di akhir pembelajaran.

\section{Metode Pembiasaan}

Pembiasaan meruapakan salah satu metode pendidikan yang sangat penting, terutama bagi anak-anak. Mereka belum menginsafi apa yang disebut baik dan buruk salam ari susila. Mereka juga belum mempunyai kewajiban - kewajiban yang harus dikerjakan seperti orang dewasa.Sehingga mereka perlu dibiasakan dengan tingkah laku, ketrampilan, kecakapan dan pola berfikir tertentu. Anak perlu dibiasakan pada sesuatu yang baik. Lalu mereka akan mengibah seluruh sifat - sifat baik menjadi kebiasaan, sehingga jiwa dapat menunaikan kebiasaan itu tanpa terlalu payah, tanpa kehilangan banyak tenaga dan tanpa menemukan banyak kesulitan (Nata, 1997:101).

Belajar kebiasaan adalah proses pembentukan kebiasaan -kebiasaan baru atau perbaikan kebiasaan - kebiasaan yang telah ada. Belajar kebiasaan, selain menggunakan perintah, suri tauladan dan pengalaman khusus juga menggunakan hukuman dan ganjaran. Tujuannya agar siswa memperoleh sikap - sikap dan kebiasaan - kebiasaan perbuatan baru yang lebih tepat dan positf dalam arti selaras dengan kebutuhan ruang dan waktu (kontekstual). Selain itu arti tepat dan positif di atas ialah 
selaras dengan norma dan tat nilai moral yang berlaku baik yang bersifat religious maupun tradisional dan kultural (Syah, 2000:123).

Pembiasaan pada pendidikan anak sangatlah penting, khususnya dalam pembentukan pribadi dan ak lak. Pembiasaan agama akan memasukkan unsur-nsur positif pada pertumbuhan anak. Semakin banyak pengalaman agama yang didapat anak melalu pembiasaan, maka semakin banyak unsure agama dalam kepribadiannya dan semakin mudahlah ia memahami ajaran agama Dari uraian diatas, dapat ditarik kesimpulan bahwa indikator metode pembiasaan itu adalah suatu cara atau jalan yang dilakukan dengan sengaja, berulang-ulang, terus-menerus, konsisten, berkelanjutan, untuk menjadikan sesuatu itu kebiasaan (karakter) yang melekat pada diri sang anak, sehingga nantinya anak tidak memerlukan pemikiran lagi untuk melakukannya. Guru sebagai pendidik dan orang tua di sekolah sangat memiliki peran penting. Karena dalam pelaksanaan metode pembiasaan ini pastilah memerlukan dukungan dari siswa. Apabila siswa tidak memiliki minat atau motivasi untuk mengkuti metode pembiasaan ini pastilah metode ini hanya akan menjadi teori.

Motivasi sangatlah dibutuhkan dalam mendukung pelaksanaan ini. Agar jiwa keagamaan dan kesadaran peserta didik dapat muncul. Sehingga mereka menjadi generasi muda umat muslim yang selalu menjaga membaca Al-Qurean karena itu merupakan pedoman hidup dan ada banyak sekali ilmu yang akan kita dapat ketika mempelajari Al-Qurean. Anak dalam melakukan proses belajar tidak terlepas dari pembiasaan diri yang muncul karena adanya faktor dari luar, bila lingkungan tempat tinggal mendukung dengan segala kebaikan maka sudah barang tentu anak akan tumbuh dan berkembang secara positif.

\section{Pengertian Disiplin}


Disiplin secara etimologi berasal dari bahasa Latin "disibel” yang memiliki arti pengikut. Sejalan dengan perkembangan zaman, kata tersebut mengalami pergeseran makna menjadi “disipline” yang artinya kepatuhan atau yang menyangkut tata tertib. Dalam mewujudkan keadaan disiplin memerlukan integritas emosi.

Dalam Kamus Besar Bahasa Indonesia disiplin diartikan ketaatan (kepatuhan) kepada peraturan (tata tertib dan sebagainya). Dalam Kamus Modern Bahasa Indonesia, disiplin diartikan ketaatan yang keras kepada peraturan. Panji Anoraga mengambil suatu kesimpulan mengenai masalah kedisiplinan. Menurutnya, bahwa disiplin adalah suatu perbuatan, sikap untuk selalu mentaati peraturan atau tata tertib. Ada dua faktor yang sangat penting yang berkaitan dengan kedisiplinan, yaitu faktor waktu dan kegiatan atau perbuatan. Tentang kedisiplinan, Malayu S.P. Hasibuan mengatakan bahwa kedisiplinan merupakan fungsi SDM yang utama, karena semakin baik disiplin pegawai, akan semakin tinggi prestasi dan etos kerja yang dapat dicapainya. Tanpa disiplin, sulit bagi sebuah organisasi/ lembaga mencapai hasil yang optimal. Disiplin yang baik akan mencerminkan besarnya tanggung jawab seseorang terhadap tugas-tugas yang diberikan kepadanya (Saputri, 2016).

Jadi, dari beberapa definisi disiplin diatas, kita bisa mengatakan dengan kata lain disiplin adalah patuh didalam menjalankan berbagai peraturan atau tunduk terhadap pengendalian juga pengawasan. Sikap yang selalu tepat janji, berprinsip dan berpegang teguh adalah merupakan salah satu sikap yang ditunjukkan oleh orang yang disiplin, sehingga orang lain menganggapnya sebagai manusia yang bertanggung jawab dan memberikan kepercayaan terhadapnya.

Menurut Ellen G White, disiplin mempunyai beberapa tujuan, diantaranya adalah sebagai perintah atas diri, menaklukan kuasa kemauan, memperbaiki 
kebiasaan-kebiasaan, mengajarkan menghormati Illahi dan orang tua, penurutan atas dasar prinsip dan menghancurkan benteng setan. Adapun menurut Emile Durkheim, tujuan dari disiplin adalah sebagai upaya untuk mengembangkan suatu keteraturan dalam tindakan manusia serta memberikan sasaran tertentu sekaligus membatasi cakrawala.

Jadi secara umum tujuan dari disiplin adalah menanamkan nilai-nilai positif agar kehidupannya menjadi lebih teratur dan memberikan kepercayaan orang lain terhadapnya. Karena dengan adanya sikap disiplin yang dimilikinya ia akan memiliki rasa tanggung jawab untuk menjalankan segala aturan dan kewajiban yang dibebankan kepadanya.

\section{Fase Perkembangan Anak Secara Umum}

Menurut beberapa para ahli, ada beberapa fase atau periodesasi secara psikologi perkembangan individu, yaitu:

\section{Periodisasi yang berdasarkan biologis}

Pada periodisasi perkembangan ini berdasarkan pada kondisi atau proses biologis tertentu. Menurut pembagian Aristoteles didasarkan atas adanya indikasi pertumbuhan jasmani yaitu antara fase pertama ( fase anak kecil: usia $0-6$ tahun ) dan fase kedua ( fase anak sekolah: 7 - 14 tahun ) dibatasi oleh pergantian gigi anak, sedangkan antara fase kedua dengan ketiga ( fase remaja: $14-21$ tahun ) ditandai dengan mulai bekerjanya kelenjar kelamin dengan lengkap.

\section{Periodisasi yang berdasarkan psikologis.}

Oswald Kroch merupakan tokoh utama yang mempelopori adanya periodesasi yang berdasarkan psikologis. Dia menganggap masa-masa kegoncangan (trotz) adalah sebagai dasar pembagian masa-masa psikologi perkembangan, karena dia meyakini 
bahwa masa kegoncangan inilah yang merupakan keadaan psikologis yang khas dan dialami oleh setiap anak dalam masa perkembangannya. Adapun fase-fase tersebut yaitu: a) masa kanak-kanak awal, dimulai dari lahir sampai masa "trotz"( kegoncangan) pertama b) masa bersekolah, dimulai dari trotz pertama sampai trotz kedua c) masa kematangan, dimulai dari trotz kedua sampai akhir remaja.

\section{Periodisasi yang berdasarkan didaktis}

Sebagaimana yang telah dikemukakan oleh Harvey A. Tilker, $\mathrm{PhD}$ dalam Developmental Psycology to day (1975) dan Elizabeth B. Hurlock dalam Developmental Psycology (1980), pada pembagian masa-masa perkembangan ini nampak sudah kelengkapan yang mencakup sepanjang hidup manusia sesuai dengan hakikat perkembangan manusia yang berlangsung sejak konsepsi sampai mati dengan pembagian periodisasinya.Berikut merupakan periodisasi berdasarkan didaktis menurut Elizabeth B. Hurlock:

1. Masa sebelum lahir ( pranatal ): 9 bulan

Periode prakelahiran (prenatal period), ialah saat dari pembuahan hingga kelahiran. Periode ini merupakan masa pertumbuhan yang luar biasa dari satu sel tunggal hingga menjadi organisme yang sempurna dengan kemampuan otak dan perilaku, yang dihasilkan kira-kira dalam periode 9 bulan.

2. Masa bayi baru lahir ( new born ): 0-2 minggu

Masa bayi (infacy), ialah periode perkembangan yang merentang dari kelahiran hingga 18 atau 24 bulan. Masa bayi adalah masa yang sangat bergantung pada 
orang dewasa. Banyak kegiatan psikologis yang terjadi hanya sebagai permulaan seperti bahasa, pemikiran simbolis, koordinasi sensorimotor, dan belajar sosial.

3. Masa bayi ( babyhood ): 2 minggu- 2 th

4. Masa kanak-kanak awal ( early childhood ): 2-6 th

Masa awal anak-anak (early chidhood), yaitu periode pekembangan yang merentang dari masa bayi hingga usia lima atau enam tahun, periode ini biasanya disebut dengan periode prasekolah. Selama masa ini, anak anak kecil belajar semakin mandiri dan menjaga diri mereka sendiri, mengembangkan keterampilan kesiapan bersekolah (mengikuti perintah, mengidentifikasi huruf), dan meluangkan waktu berjam jam untuk bermain dengan teman-teman sebaya.

5. Masa kanak-kanak akhir ( later chilhood ): 6-12 th

Masa pertengahan dan akhir anak-anak (middle and late childhood), ialah periode perkembangan yang merentang dari usia kira-kira enam hingga sebelas tahun, yang kira-kira setara dengan tahun-tahun sekolah dasar, periode ini biasanya disebut dengan tahun-tahun sekolah dasar. Keterampilan-keterampilan fundamental seperti membaca, menulis, dan berhitung telah dikuasai.

6. Masa puber ( puberty ) 11/12-15/16 th

Karakteristik tahap ini adalah diperolehnya kemampuan untuk berpikir secara abstrak, menalar secara logis, dan menarik kesimpulan dari informasi yang tersedia. Dalam tahapan ini, seseorang dapat memahami hal-hal seperti cinta, bukti logis, dan nilai. Ia tidak melihat segala sesuatu hanya dalam bentuk hitam dan putih, namun ada "gradasi abu-abu" di antaranya. Dilihat dari faktor biologis, tahapan ini muncul saat pubertas (saat terjadi berbagai perubahan besar lainnya), 
menandai masuknya ke dunia dewasa secara fisiologis, kognitif, penalaran moral, perkembangan psikoseksual, dan perkembangan sosial.

7. Masa remaja (adolesence) : $15 / 16-21$ th

Masa remaja (adolescence), ialah suatu periode transisi dari masa awal anakanak hingga masa awal dewasa, yang dimasuki pada usia kira-kira 10 hingga 12 tahun dan berakhir pada usia 18 tahun hingga 22 tahun. Masa remaja bermula pada perubahan fisik yang cepat, pertambahan berat dan tinggi badan yang dramatis, perubahan bentuk tubuh, dan perkembangan karakteristik seksual seperti pembesaran buah dada, perkembangan pinggang dan kumis, dan dalamnya suara. Pada perkembangan ini, pencapaian kemandirian dan identitas sangat menonjol (pemikiran semakin logis, abstrak, dan idealistis) dan semakin banyak menghabiskan waktu di luar keluarga.

8. Masa dewasa awal ( early adulthood ) : 21-40 th

Masa awal dewasa (early adulthood), ialah periode perkembangan yang bermula pada akhir usia belasan tahun atau awal usia dua puluhan tahun dan yang berakhir pada usia tiga puluhan tahun. Ini adalah masa pembentukan kemandirian pribadi dan ekonomi, masa perkembangan karir, dan bagi banyak orang, masa pemilihan pasangan, belajar hidup dengan seseorang secara akrab, memulai keluarga, dan mengasuh anak anak.

9. Masa dewasa madya ( middle adulthood ): 40-60 th

Masa pertengahan dewasa (middle adulthood), ialah periode perkembangan yang bermula pada usia kira-kira 35 hingga 45 tahun dan merentang hingga usia enam puluhan tahun. Ini adalah masa untuk memperluas keterlibatan dan tanggung jawab pribadi dan sosial seperti membantu generasi berikutnya menjadi individu 
yang berkompeten, dewasa dan mencapai serta mempertahankan kepuasan dalam berkarir.

10. Masa usia lanjut ( later adulthood) : 60-....

Masa akhir dewasa (late adulthood), ialah periode perkembangan yang bermula pada usia enam puluhan atau tujuh puluh tahun dan berakhir pada kematian. Ini adalah masa penyesuaian diri atas berkurangnya kekuatan dan kesehatan, menatap kembali kehidupannya, pensiun, dan penyesuaian diri dengan peran peran sosial baru.

\section{Fase Perkembangan Anak Menurut Fikih Islam}

Dalam fase perkembangan anak manusia hingga dweasa dikenal dengan istilah ash-shoghir, mumayyiz dan baligh.

1. Fase Pertama (As-shoghir)

Fase pertama masa ini dimulai sejak bayi lahir hingga pada masa tamyiz. Yaitu ketika ia menginjak usia tujuh tahun, dalam Islam, anak dalam usia ini lebih banyak menerima haknya dari pada menjalankan kewajiban ( ahliyyah al-wujub ). Memang dalam Islam terdapat beberapa kewajiban yang sudah dibebankan kepada anak kecil seperti zakat dan mengganti barang orang lain yang dirusak. Itupun yang harus menunaikan adalah orang tua selaku walinya. Sehingga dapat dikatakan sesungguhnya didalam Islam, anak kecil belum dikenai kewajiban apa - apa karena itu disebut sebagai ghoiru mukallaf ( bukan merupakan orang yang terkenan beban ). Rasullah SAW bersabda :

$$
\text { رفع القلم عن ثلاثة عن النائم حتى يستيقظ، و عن الصبي حتى يبلغ، و عن المنون حتى يعقل }
$$


Rasulullah shallallahu 'alaihi wa sallam bersabda: "Diangkat pena dari 3 ( kelompok manusia ) dari orang : orang yang tidur sampai dia bangun, dari anak kecil hingga ia dewasa, dan dari orang gila sampai ia sadar" HR. Ahmad

Menurut makna dari hadits ini, Allah menghilangkan pembebanan ( taklif) dari bayi ataupun anak kecil sehingga ia dewasa. Hal ini memberikan petunjuk secara jelas bahwa anak kecil tidak dibebani dalam menjalankan syariat Islam. Adapun jika ada yang mengatakan pembayaran diyat dibebankan kepadanya, maka hal tersebut bertentangan dengan hadits ini.

Manusia didalam fase kanak-kanak seperti ini belum layak untuk dibebani tugas mengingat masih lemahnya kondisi fisiknya. Akal, pikiran dan mentalnya pun belum mampu memahami apa yang diperintahkan dalam syariat. Dengan kondisi yang seperti ini maka atas rahmat dan keagungan-Nya Allah tidak menghendaki adanya beban yang ditanggung oleh anak kecil dengan tugas yang harus dilaksanakannya sendiri. Anak kecil juga tidak dituntut dan dihukum fisiknya atas segala perilaku ataupun perbuatan yang menyimpang dari kebenaran. Baik penyimpangan tersebut secara ucapan maupun perbuatan. Fase inipun tidak dibebani tanggung jawab untuk melaksanakan perbuatan orang lain. Segala kewajibanpun dihilangkan.

Meski demikian, fase ini memiliki beberapa hak secara sempurn untuk diperlakukan secara baik oleh yang lain. Atau dengan kata lain adanya kewajiban yang harus dilakukan oleh orang lain terhadap anak - anak demi kemaslahatannya. Adapun hak-hak dasar yang dimiliki pada fase ini adalah :

1. Hak Pangan

2. Hak Sandang

3. Hak Papan ( Tempat Tinggal ) 
4. Hak pelayaan Kesehatan

5. Hak Pendidikan dan Mengembangkan Diri

6. Hak Mendapatkan Perlindungan ( Perlindungan Fisik, Perlindungan mosional, Perlindungan Seksual, Perlindungan Penelantaran )

\section{Hak Bermain}

\section{Hak Berpartisipasi}

Perlu diketahui, pada fase ini anak-anak belum layak mendapatkan hukuman dari berbagai perilaku yang menyimpang dari kebenaran dikarenakan kelemahannya baik secara fisik maupun mentalnya.

\section{Fase Kedua}

Fase ini dimulai sejak usia tamyiz, yakni senggang waktu anata usia 7 ( tujuh ) sampai dengan usia dewasa. Manusia pada usia ini belum memiliki kelayakan didalam menjalankan ( $\left.a l-a d a^{\prime}\right)$ syariat secara sempurna. Karena didalam menjalankan syariat secara sempurna memerlukan 2 kemampuan, yaitu : kemampuan didalam memahami khithab ( kewajiban ) yang bisa dibuktikan dengan adanya akal dan pikiran serta kemampuan didalam melaksnakan syariat yang akan terpenuhi dengan badan yang kuat.

Atau secara garis besarnya seseorang dinyatakan layak dalam menjalankan syariat secara sempurna adalah harus memiliki standart kriteria kemampuannya dalam segi kekuatan fisik maupun mentalnya.

Didalam fase ini manusia belum mencapai kesempurnaannya sebagai manusia baik dari segi akal maupun fisik.karena ia lahir dari permualaannya, belum memiliki kesempurnaan akal dan jasmaninya. Meskipun ia telah memiliki persiapan dan 
kepantasan untuk memiliki sampai pada gilirannya mencapai kesempurnaanya, yakni dewasa dan berakal secara sempurna.

Secara umum, pada masa tamyiz itu manusia telah memiliki ahliyyat al-wujub secara sempurna dan ahliyyat al ada' yang minim karena memiliki kemampuan yang minim sebagai konsekwensi dari ketidakberdayaan akalnya.

Namun perlu diketahui, pada fase ini anak - anak masih belum memiliki dosa karena belum belum taklif ( dibebankan segala kewajiban syariat padanya ), namun apabila ia melaksanakan ibadah maka ia tetap mendapatkan catatan amal mulia dihadapan Allah.

3. Fase ketiga,

Fase ini dimulai dari masa remaja dalam Islam yang disebut dengan usia baligh ( al-baligh ). Secara etimologis, baligh berarti al-wushul wal idrok yang berarti sampai dan mengenal atau memahami. Dalam istilah Arab disebut juga dengan istilah balagho al-ghulam yang berarti anak telah mampu memahami. Sedang menurut makna terminologis, al-bulugh adalah habisnya masa kanak-kanak. Dari fase inilah manusia dikatakan sebagai mukallaf dalam artian segala kewajiban syariat Islam telah dibebankan kepadanya dengan syarat ia berakal dan telah masuk usia baligh.

\section{Pentingnya Pendidikan dalam Lingkungan Keluarga}

Tugas keluarga dalam mendidik anak membutuhkan peran serta dari pendidikan di sekolah dan lingkungan masyarakatnya. Sebagaimana apa yang telah diungkapkan oleh Ahmad Tafsir bahwa ilmu pendidikan Islam adalah ilmu pendidikan yang bedasarkan Islam. Selanjutnya Ahmad Tafsir mendifinisikan pendidikan sebagai bimbingan yang diberikan pada seorang agar ia berkembang secara maksimal sesuai dengan ajaran Islam. 
Berdasarkan beberapa teori di atas, teori-teori pendidikan Islam sekurangkurangnya membahas permasalahan sebagai berikut : 1. Pendidikan dalam keluarga 2. Pendidikan sekolah 3. Pendidikan dalam masyarakat, yang kesemuanya itu mengarah pada pendidikan jasmani, akal dan hati. Atau dengan kata lain, pelaksanaan pendidikan Islam tidak hanya formal tetapi juga informal dan non formal, sehingga pendidikan Islam dapat dilaksanakan di lingkungan keluarga, sekolah, dan masyarakat.

Dasar pijakan lain yang relevan dengan pemaknaan ini adalah tiga teori ilmuan barat, yaitu: Pertama, nativsisme yang menyatakan bahwa perkembangan manusia hanya ditentukan oleh pembawaan, dalam artian dalam perkembangan individu itu semata-mata hanya tergantung pada faktor dasar. Tokoh utama aliran ini adalah Schopenhuen.

Kedua, sebagai sintesis dari teori pertama adalah teoeri empirisme yang menyatakan bahwa perkembanggan manusia hanya di tentukan oleh faktor lingkungannya. Tokoh dari aliran ini adalah Jhon Locke. Aliran ini banyak berkembang di Amerika Serikat yang pada akhirnya para ilmuan negeri ini melanjutkan teori yang terkenal dengan environmentalisme. Sebab mereka yakin bahwa sangat dominan dalam kehidupan manusia adalah lingkungannya.

Ketiga, sebagai sitensis dari kedua teori diatas, yakni teori konverdensi yang menyatakan bahwa tidak hanya pembawaan atau lingkungan saja yang bisa mempengaruhi perkembangan kejiwaan manusia, melainkan gabungan dari keduaduanya. Tokoh dari aliran ini adalah William Stern.

Dan inilah yang sangat relevan dengan teori perkembangan kejiwaan Islam, di mana telah dinyatakan dalam hadis Nabi yang diriwayatkan oleh Imam Bukhori 
Artinya: " Tiap orang dilahirkan membawa fitrah, ayah dan ibunya lah yang menjadikan yahudi. Nasrani dan majusi.

\section{Tela'ah Hadits Nabi Tentang Perintah Mengajarkan Anak dalam}

\section{Menjalankan Shalat}

Qur'an dan hadits merupakan dasar sumber hukum Islam. Al-Quran adalah kalamullah yang diturunkan kepada Nabi Muhammad SAW melalui Malaikat Jibril yang diriwayatkan secara mutawatir yang tertulis didalam mushaf dan berfungsi ibadah bagi pembacanya. Ia merupakan undang - undang teringgi dalam Islam. Adapun hadits merupakan interpretasi praktis ( at-tafsir al-amaly) atas Al-Qur'an disamping juga implementasi riil ( at-tahqiq al-waqi'i) dan ideal ( al-mitsal ) dari Islam. Ia merupakan sabda, perilaku, sikap ataupun ikrar Rasul. Disebutkan dalam Hadits yang diriwayatkan oleh Imam At-Tirmidzi, Rasulullah SAW bersabda, "Ajarkanlah anakmu tata cara shalat ketika telah berusia tujuh tahun. Dan pukullah dia pada saat berusia sepuluh tahun (apabila meninggalkannya).” (Riwayat Tirmidzi).

Hadits ini memerintahkan kepada kita selaku orang tua agar memerintahkan anak untuk sholat. Secara bahasa shalat berarti doa. Adapun menurut istilah shalat adalah suatu ibadah yang diawali dengan takbiratul ihram dan diakhiri dengan salam yang disertai dengan syarat dan rukun yang telah ditentukan oleh syara'. Ia merupakan pilar agama. Setiap orang yang merasa dirinya muslim maka konsekwensi baginya adalah menjalankan syariat tersebut. Shalat merupakan interaksi secara horisontal antara hamba dengan Khaliq secara lisan dan perbuatan yang disertai dengan kehadiran kalbu. Ia pun menjadi tolok ukur bagi kehidupan manusia didalam tindak tanduknya, maksudnya ketika seseorang mampu menjaga kewajiban tersebut dengan 
sempurna maka secara otomatis kehidupannyapun akan semakin baik dan benar. Karena nilai- nilai keislaman telah mengkristal didalam jiwanya.

Didalam hadits tersebut, secara jelas Nabi menyebutkan shalat sebagai obyek dalam pendidikannya dikarenakan urgensi dari shalat itu sendiri. Perintah tersebut juga bisa mewakili untuk mendidik anak-anaknya didalam menjalankan kewajiban syariat Islam yang lain yang bersifat " fundamen ".

Selain itu, hadits tersebut juga menggambarkan metode pembelajaran oleh Nabi dalam mengaplikasikan metode perintah, metode pembiasaan serta metode hukuman serta ganjaran.

Sebagaimana pemaparan sebelumnya, disiplin berasal dari kata disciplina dan discipulus, yang berarti instructrion dan student atau petunjuk dan murid. Hal ini menujukkan bahwa disiplin itu tidak lain adalah sebagai upaya dalam mendidik anak terutama didalam hal sikap dan perilaku. Disiplin memberlukan pembiasaan yang dilakukan secara kontinyu atau rutin.

Disiplin adalah memberikan petunjuk hingga anak mampu mengontrol dan mengendalikan diri, bertanggungjawab kepada Allah serta mampu bekerjasama dengan baik hingga membentuk kepribadian yang menarik dan menyenangkan.

Agar sukses didalam menanamkan kedisiplinan terhadap anak, ada beberapa hal yang harus disadari oleh setiap orangtua yaitu meyakini bahwa anak merupakan anugrah dan amanah dari Allah SWT. Tidak semua orang tua disberikan anugrah tersebut. Dengan anugrah tersebut berarti kita diberikan kesempatan mengasuh anakanak membesarkan dan mengarahkan pendidikannya.

Adapun obyek atau sasaran pendidikan dalam hadits ini adalah anak yang berusia 7 tahun. Sesuai dengan pemaparan sebelumnya, pada usia ini adalah awal anak 
dalam memasuki masa tamyiz yang masih belum sempurna didalam menjalankan syariat Islam dikarenakan keterbatasan mental, akal dan pikirannya didalam memahami khitab secara utuh disamping memiliki fisik yang masih lemah

Meskipun begitu, sebagai seorang penanggung jawab dalam pendidikan anak, baik sebagai orang tua maupun guru berkewajiban untuk mengajarkan,mendidik dan mengarahkan dalam pendidikan dan masa depan anak terutama dalam bidang keagamaan. Termasuk diantaranya adalah memerintahkan anak untuk menjalankan shalat 5 waktu yang merupakan salah satu dari rukun Islam.

Begitupun juga secara umum, pada usia 7 tahun berarti ank memasuki fase pertengahan atau masa kanak-kanak akhir ( later chilhood) dimana pada usia tersebut anak mengalami perkembangan yang merentang dan mulai mampu mengaenal ketrampilan-ketrampilan dasar. Dalam usia ini, pengendalian diri anak mulai lebih meningkat yang mana prestasi merupakan tema yang lebih sentral dari dunia anak. Secara umum anak mulai dapat mengenal dunia yang lebih luas dan pendidikan secara formal. Untuk itulah, didalam aturan pendidikan di negara kita, anak dapat mengawali sekolah dasar atau pendidikan formal adal ketika anak setidaknya telah memasuki usia 7 tahun.

Dari sinilah anak mulai diajarkan hal-hal yang bersifat fundamental dalam syariat untuk membiasakan shalat. Karena pembelajaran yang ditanamkan sejak awal akan memiliki nilai yang lebih maksimal dengan membentuk watak dan karakter anak. Dan seiring dengan bertambahnya usia, anak akan terbiasa menjalankan ibadah tersebut secara ringan tanpa menjadikannya beban. Untuk itulah diperlukannya metode pembiasaan dalam menanamkan kedisiplinan anak. 
Adapun penanaman kedisiplinan yang dilakukan orang tua atau guru terhadap anak hendaklah dilakukan dengan cara kasih sayang. Hal ini dimaksudkan sebagai upaya pencegahan atau bereaksinya anak terhadap tingkah laku yang tidak layak,mempertimbangkan perasaan dibalik perilaku anak, membantu anak untuk memiliki kesadaran diri dan menggunakan akal dan pikarannya secara optimal serta menekankan pada proses belajar sehingga mencapai makna " disiplin" yang diharapkan.

Sebagaimana dijelaskan oleh Andi Sri Suriati Amal dalam bukunya, Role Jugling, ada lima langkah pendekatan didalam menanamkan kedisiplinan anak yang dilakukan dengan kasih sayang yaitu, memikirkan perasaan anak, mengajukan pertanyaan untuk mengubah tingkah laku, mengajarkan ketrampilan untuk tidak mengulangi tingkah laku yang negatif, menggunakan kalimat-kalimat yang singkat ( maksimal dua kalimat ) serta fokus pada hal-hal yang positif.

Berawal dari pembiasaan sejak kecil itulah, peserta didik membiasakan dirinya melakukan sesuatu yang lebih baik. karena menumbuhkan kebiasaan yang positif ini tidaklah mudah, akan memakan waktu yang panjang. Namun, bila sudah menjadi kebiasaan, akan sulit pula untuk berubah dari kebiasaan tersebut. Penanaman kebiasaan yang baik, sebagaimana sabda Rasulullah SAW di atas, sangat penting dilakukan sejak awal kehidupan anak. Agama Islam sangat mementingkan pendidikan kebiasaan, dengan pembiasaan itulah diharapkan peserta didik mengamalkan ajaran agamanya secara berkelanjutan. Beberapa metode dapat diaplikasikan dalam pembiasaan ini."Metode mengajar yang perlu dipertimbangkan untuk dipilih dan digunakan dalam pendekatan pembiasaan antara lain : metode latihan (drill), metode pemberian tugas, metode demonstrasi dan metode eksperimen." 
Dengan langkah tersebut orang tua bisa memahami cara berfikir anak untuk bisa mendisiplinkannya, beralih dari model hukuman yang menyakitkan ke model pendisiplinan yang efektif dan tidak merusak harga diri serta kepercayaan diri anak.

\section{KESIMPULAN}

Pada dasarnya anak anak itu sangat peka dengan harapan orang dewasa. Untuk itu,dalam menerapkan disiplin hendaknya setiap orang tua memberikan harapan yang positif terhadap anak, memberikan motifasi dan penghargaan yang tulus melalui pujian terutama pada hal-hal yang positif. Karena dengan pujian sesederhana apapun mampu secara efektif membangun rasa percaya diri dan harga diri secara positif. Dalam artian penanaman kedisiplinan dengan kasih sayang. Dengan demikian, penggunaan metode pembiasaan sebagai upaya pendidik dalam menanamkan kedisiplinan anak dalam menjalankan ibadah dapat tepat sasaran. Karena fungsi disiplin itu sendiri adalah sebagai implementasi harapan dan keinginan pendidik terhadap anak agar anak memiliki kepribadin yang bermartabat. 


\section{REFERENSI}

Abu Ahmadi, Strategi Belajar Mengajar, (Bandung, Pustaka Setia, 1997)

Abudin Nata, Filsafat Pendidikan Islam, (Jakarta: Logos Acana Ilmu, 1997)

Ahmad tafsir, ilmu pendidikan dalam perspektif islam. ( Bandung : Remaja Rosdakarya, 1994)

Andi Sri Suriati Amal, Role Jugling, Perempuan Sebagai Muslimah, Ibu dan Istri (Jakarta: Kompas Gramedia, 2013)

Cholil Nafis, Fikih Keluarga Menuju Keluarga Sakinah, Mawaddah, wa Rahmah. Keluarga Sehat, Sejahtera dan Berkualitas, (Jakarta: Mitra Abadi Press, 2009), 238

Muhibin Syah, Psikologi Pendidikan ( Bandung: Remaja Rosdakarya , 2000 ),123

Nana Sudjana, Dasar-dasar Proses Belajar Mengajar, (Bandung: Sinarbaru Algesindo, 2005)

Su'udy, Kumpulan Dasar Ilmu Pendidikan Sebagai Pengantar Ilmu Pendidkan, (Perguruan Islam Mathali'ul Falah, tt)

Dosen Psikologi.com, 20 Macam Metode Pembelajaran Lengkap, diakses dari https://dosenpsikologi.com/macam-macam-metode-pembelajaran pada 7 Juli 2017

Wikipedia. (Disiplin) diakses dari https://id.wikipedia.org/wiki/Disiplin pada 9 Februari 2017

Rhen Hana Word, Fase-fase Perkembangan Manusia diakses dari https://rhenniyhanasj.wordpress.com/2014/05/25/fase-fase-perkembanganmanusia/ pada 25 Mei 2014

Arining Tias Saputri, Penanaman Nilai Kemandirian Dan Kedisiplinan Bagi Anak Usia Dini Siswa Tk B Di Kelompok Bermain Mutiara Hati Purwokerto. Skripsi Thesis, (IAIN Purwokerto, 2016), diakses dari http://repository.iainpurwokerto.ac.id/307/ pada 25 Mei 2014

Dedy Ryner, Pengertian Disiplin, Tujuan, Macam, Manfaat, Contoh Disiplin Terlengkap, diakses dari http://www.spengetahuan.com/2017/08/pengertiandisiplin-tujuan-macam-manfaat-contoh-disiplin.html pada 13 Agustus 2017 
Zaky, Metode Pembelajaran Menurut Para Ahli Secara Umum, diakses dari https://www.zonareferensi.com/pengertian-metode-pembelajaran/, pada 16 Maret 2018 